\title{
Algılanan Lüks Marka Değerinin ve Marka İtibarının Premium Fiyat Ödeme İstekliliği Üzerindeki Etkisi
}

DOI: $10.26466 /$ opus.572789

\author{
Özge Habiboğlu ${ }^{*}$ - Aypar Uslu** \\ * Öğr. Gör., Namık Kemal Üniversitesi, Tekirdağ \\ E-Posta: ohabiboglu@nku.edu.tr \\ ORCID: $\underline{0000-0001-5312-5024}$ \\ **Prof. Dr., Marmara Üniversitesi, İstanbul \\ E-Posta: auslu@marmara.edu.tr \\ ORCID: $\underline{0000-0002-6994-9367}$
}

Öz

Lüks mallar tarihin her döneminde bireyler için ilgi çekici ve satın alma arzusu uyandıran mallar olarak yer almıştır. Lüks malların diğer mallardan ayrılmasında önemli bir etken ise sahip olmak isteyenlere sunduğu değerler olmaktadır. Lüks malların değer önermeleri ise tarih içerisinde değişmiş ve daha karmaşık hale gelmiştir. Sunulan değer önermesinin bedeli olarak ise işletmeler bu mallar için özel ve yüksek fiyatlar belirlemektedirler. Lüks mallar karşısında işletmelerin premium fiyatlar istemesi, tüketicilere sundukları değerlerle tüketici beklentilerini karşıladığında kabul görmektedir. Mevcut araştırmanın amacı tüketicilerin premium fiyat ödeme istekliliğine etki eden faktörleri araştırmaktır. Araştırma modelinde marka itibarı ve algılanan lüks marka değerinin Premium fiyat ödeme istekliliği üzerindeki etkisi araştırılmıştır. Araştırma kapsamında kolayda örneklem ile 273 anket yapılmıştır. Lüks marka değeri altında fonksiyonel değer, deneyimsel değer ve sembolik değerin etkisi ölçülmüştür. Çalışma bulgularında marka itibarının hem algılanan marka değeri boyutlarına hem de premium fiyat ödeme istekliliğine anlaml bir etkisi olduğu bulunmuştur. Ayrıca algılanan değer boyutlarından fonksiyonel değer ve deneyimsel değerin de premium fiyat ödeme istekliliği üzerinde anlamlı bir etkisi olduğu elde edilmiştir.

Anahtar Kelimeler: Lüks markalar, Algılanan değer, Marka itibarı, Premium fiyat ödeme istekliliği, Marka Değeri 


\title{
The Effect of Perceived Luxury Brand Value and Brand Reputation on Willingness to Pay Price Premium
}

\begin{abstract}
During history, luxury goods have been an interesting and demanding goods for individuals. An important factor in the separation of luxury goods from other goods is the values it offers to those who wish to own. The value propositions of luxury goods have changed and become more complex in history. As the return of the value proposition offered, the companies set special and high prices for these goods. The fact that companies demand premium prices against luxury goods is accepted when they meet consumer expectations with the values they offer to consumers. The aim of the present research is to investigate the factors that affect consumers' willingness to pay price premium. In the research model, the effect of brand reputation and perceived luxury brand value on the willingness to pay price premium was investigated. Within the scope of the study, 273 questionnaires were conducted with convenience sampling method. Under the luxury brand value, the effect of functional value, experiential value and symbolic value was measured. In the study findings, it was found that brand reputation has a significant effect on both perceived brand value dimensions and willingness to pay premium price. In addition, functional value and experiential value of perceived value dimensions had a significant effect on willingness to pay premium price.
\end{abstract}

Keywords: $\quad$ Luxury brands, Perceived value, Brand reputation, Willingness to pay premium price, Brand Value 


\section{Giriş}

Günümüz rekabetçi pazar ortamında bir işletmenin, hedef müşterilerinin gözünde markasını rakip markalara karşı farklı kılma becerisini geliştirmesi için tüketicilerinin algılarını ve marka değerini oluşturan faaliyetleri yönetmesi önemlidir. Tüketiciler için ürünü farklı kılan birçok önemli unsur olmakla birlikte bir unsur da markanın lüks olabilme seviyesidir.

Bir markanın lüks olarak algılanması sunduğu kaliteden çok daha fazlasını içermektedir. Tüketici tarafından, satın alınan ürünün hissettirdiği duygular ve sosyal çevrenin ürüne olan tutumu ürünü farklı ve önemli kılan unsurlar arasında yer almaktadır. İşletme tarafından ise ürünün lüks olarak algılanması için marka yönetiminin başarılı bir şekilde sürüdürülmesi gerekmektedir. İşletme tarafından sunulan lüks marka değelerinin tüketiciler tarafından algılanması işletmelerin ürünlerine yüksek fiyat koymalarına da olanak sağlamaktadır. Mevcut çalışma tüketicilerin premium fiyat ödemelerinde algilanan marka değerinin ve marka itibarının etkisini ölçmektedir. Marka itibarının algılanma düzeyi üzerinde etkisinin olup olmaması araştırmada bakılan başka bir önemli noktadır. Literatürde markaların algılanan değerinin premium fiyat ödeme üzerine olan etkisini inceleyen çalışmalar bulunmakta olup, mevcut çalışma marka itibarı değişkeni ile literature katkı sağlamaya çalışmıştır. $\mathrm{Bu}$ amaçla toplanan birincil veriler ile ilişkilerin varlığı incelenmiştir.

\section{Lüks Marka}

Lüksün tüketiciler ifade ettiği anlam zaman içerisinde değişim geçirebilmektedir, tüketiciler uzun süre boyunca lüks diye tanımladıkları mal veya hizmetlere sahiplerse, o ürünler lüks kategorisinden çıkıp normal ürün kategorisine geçebilmektedir. Lüks mallara yönelik geleneksel pazarlama çabaları işletmeleri başarıya götürmekte yetersiz kaldığında lüks malların pazarlama çabaları giderek daha karmaşık hale gelmiştir, pazarlamacıların görevi sadece kalite, performans ve özgünlük imajını iletmekle yeterli kalmayıp, aynı zamanda tüketicilerin yaşam tarzı 
yapılarıyla ilişkilendirerek bir deneyim de satmaya çalışmaktır (Atwal ve Williams, 2009, s.338).

Lüks akımıyla ilgili en eski duyumlar 17.yy'ın ortalarında yer almaktadır (Oxford, 2017). İnsanlık tarihinde lüks ürünler çeşitli şekillerde insanların yaşamında yer almıştır, nadir inciler, kristaller, parfümler, Karayipler'deki baharatlar gibi. 19.yy ve 20. yy'ın başlarında, dünya ticaretinin yükselişi ile birlikte lüks kavramı usta el ürünleri haline gelmiştir. Sanayileşmiş dünyada ise, kitlesel üretim ile lüks, el ustalarının ötesinde, rüyaların, imajların, işaretlerin ve motiflerin dünyasını çağırmak için marka tarafından özenle hazırlanmış simgeler haline gelmiştir (Berthon, Pitt, Parent, Berthon, 2009, s. 45).

Lüks mallar, kullanılmaları ve/veya gösterilmeleri yoluyla fonksiyonel yarar sağlamanın yanında ayrıca sahibine psikolojik yarar sağlayan ve prestij getiren mallardır (Kapferer ve Valette-Florence, 2016, s.121; Nia ve Zaichkowsky, 2000, s.487; Vigneron ve Johnson, 2004, s.486). Lüks, onu karşılayabilecek sınırlı bir kesim için niş bir şekilde başlamıştır, ancak günümüzdeki lüks farklıdır, daha geniş bir kitleyi hedefleyen, aktif büyüyen bir sektördür. Lüks algısının aktarımında önemli yeri olan günümüz lüks mağazaları başkentlere yayılmıştır, önemli bir nüfus sahip gelişmekte olan ekonomiler için lüks mağazaların varlığı ülkenin ekonomik büyümesinin ve orta kesimin lüks markalara ulaşma isteğinin işaretidir (Kapferer ve Valette-Florence, 2016, s.120).

Lüks ve lüks marka kavramının tanımlanması ve içerdiği nitelikler bakımından birçok çalışma yapılmıştır. Tablo 1'de lüks ve lüks marka tanımına yönelik çalışmalara geniş ölçüde yer verilmiştir ${ }^{1}$. Literatürde lükse ve lüks markalara yönelik genel kabul görmüş bir tanımlama yapılmasa da lüks markaların içermesi gereken ortak özellikler konusunda genel bir kabul görülmektedir.

Araştırmacılar lüks marka konusunu çeşitli şekillerde ele almışlardır. Kapferer (1998),Vigneron ve Johnson (2004), ve Dubois, Laurent ve Czellar (2001) yaptıkları çalışmaları da geliştirerek yirmi maddelik, beş boyutttan oluşan lüks marka indeksini geliştirmişlerdir. Dubois, Czellar ve Laurent (2005), tüketicilerin lükse yönelik tutumlarına dayanan uluslararası bir segmentasyon yaparak tüketici tutumlarını üç segmentte gruplamıştır.

${ }^{1}$ Tablo 1'de yer alan "*” tanımlar 
Christodoulides, Michaelidou ve Li (2009), tüketiciler üzerinde lüks markaları incelemiş, analiz için Vigneron ve Johnson' ın (2004) geliştirmiş olduğu ölçeğin psikometrik özelliklerini araştırmıştır. Atwal ve Williams (2009), uzun dönemli başarı için markayla ilgili deneyimlerin lüks marka tüketicileriyle bağlantı kurmaya etkisini araştırmıştır.

Nueno ve Quelch (1998), Keller (2009), Kapferer ve Bastien (2009), Kapferer (2012), Uggla (2016), Kapferer ve Valetta-Florence (2016) işletmelerin lüks marka yönetimlerini incelemişlerdir. Godey, Lagier ve Pederzoli (2009) ve Dubois ve Duquesne (1993), lüks tüketim mallarının, seçici dağıtım kanalları vasıtasıyla premium fiyatlarla satılabildiğini belirtmişlerdir. Truong, McColl ve Kitchen (2010) ve Lee ve Hwang (2011), tüketicilerin psikolojik ihtiyaçlarının lüks marka tercihine olan etkisini araştırmışlardır. Heine ve Phan (2011), lüks ürün kavramını tanımlamaya yönelik çalışmıştır. Gil, Kwon, Good ve Jonhson (2012), sosyal tüketim motivasyonlarının gençlerin lüks markalara yönelik tutumlarını nasıl etkilediğini incelemişlerdir. Kim, Ko, Xu ve Han (2012), tüketicilerin lüks markalara yönelik tutumu, müşteri sadakati etkenleri ve müşteri yaşam boyu değeri arasındaki ilişkiyi incelemişlerdir. Lee, Phau ve Roy (2012), çalışmalarında statü arayan ve statü aramayan tüketicilerin yerli ve yabancı lüks markalarına yönelik satın alma davranışlarında farklılık olup olmadığını araştırmaktadır. Hudders, Pandelaere ve Vyncke (2013), lüks marka anlamını tüketici kalite, estetik ve ayrıcalık sunma özelliklerine bakarak belirlemişlerdir. Roper, Caruana, Medway ve Murphy (2013), lüks marka tüketimine söylemsel (discursive) bir bakış açısını sunmuştur. Veg-Sala ve Roux (2014), lüks sektörde marka genişlemesi üzerinde çalışmıştır. Yang ve Mattila (2014), ürün türünün ve tüketici statü ihtiyacının lüks markalara yönelik tutumunun üzerindeki etkisinin incelemişlerdir. Lee, Edwards, Youn ve Yun (2018), genç tüketicilerin lüks marka satın alma davranışlarına kültürel farklılıkların etkisini incelemişlerdir. Wang, Soesilo ve Zhang (2015), lüks marka perakendecilerin birlikte markalama stratejilerinin etkisini kültürler arası incelemişlerdir. Phau, Teah ve Chuah (2015), tüketicilerin kötü koşullarda üretilen lüks mallara yönelik tutumlarını değerlendirmeyi amaçlamışlardır. Parguel, Delecolle ve Florence (2016), fiyat gösteriminin lüks sektördeki etkisini incelemişlerdir. Shukla, Banerjee ve Singh (2016), tüketicilerin lüks mallara olan bağlılı̆̆ının öncüllerini ve 
sonuçlarını araştırmıştır. Jain ve Schultz (2019), dijital platformların ve diğer boyutların tüketicilerin lüks markaları satın alma davranışlarına olan etkisini araştırmışlardır

Godey ve diğ. (2013), uluslararası kapsamda lüksün ve lüks markaların algılanması üzerine bir araştırma gerçekleştirmişlerdir. Fuchs, Prandelli, Schreier ve Dahl (2013), lüks markaların kullanıcı dizaynının yarattığ olumsuz algının giderilmesine yönelik çalışmışlardır. Kemp (1998), bireylerin lüks algısının fiyat elastikiyeti ile güçlü bir şekilde ilişkili olduğunu, lüks malların gereksinim duyulan mallardan -destek gerekmeyen durumlarda- olumlu bir şekilde ayrıldığını belirtmiştir. Sweeney ve Soutar (2001), tüketicilerin marka düzeyinde dayanıklı tüketim mallarının değerine ilişkin algılarını analiz etmeye çalışmıştır. Hassan, Mehmedovic ve Duverger (2015), algilanan marka globalliği ile algılanan marka lüksü arasındaki ilişkiyi araştırmışlardır. Riley, Pina ve Bravo (2015), lüks sektörde premium markalara yönelik, marka tutumu, algilanan uyum, genişleme tutumun algılanan değere olan etkisini ve tüketicilerin satın alma niyetinde algilanan değerin etkisini incelemişlerdir. Yoo ve Park (2016), tüketicilerin algılanan değerlerinin boyutlarının belirlemeye çalışmışlardır. Kapferer ve Laurent (2016), uluslararası bir çalışma yaparak tüketicilerde lüks ürün algısının hangi fiyat seviyesinden başladığını bulmaya çalışmışlardır. Lacroix ve Jolibert (2017), üç lüks markanın algılanan değerlerine göre kişisel miras değerini incelemişlerdir. Audrin, Brosch ve Sander (2017), lüks ve lüks olmayan markaların tüketici tercihine olan etkisi ve bu ilişkiye materyalizmin etkisini incelemişlerdir. Mevcut çalışma ise lüks mallara yönelik premium fiyat ödeme istekliliğine marka itibarı ve algılanan değerlerin etkisini incelemiştir.

Literatürde yapılmış olan çalışmalar göz önüne alındığında lüks marka olarak kabul edilen ürünlerin aşağıdaki özellikleri taşıması beklenmektedir:

- Lüks marka ürünleri, göze hoş gelen, estetik, nadir ve benzersiz olmalıdır,

- Lüks marka ürünleri, sahibine dikkat çekicilik, ayrıcalık, statü ve prestij getirmelidir,

- Lüks marka ürünlerinin soyut faydaları fonksiyonel faydalarında daha ağırlıklı olmalıdır, 
- Lüks marka ürünleri, yüksek kaliteli, ikonik ve yüksek fiyatlı olmalıdir,

- Lüks marka ürünleri, ulaşılabilir ancak premium fiyatlı olmalıdır,

- Lüks markalar bilinen ancak her yerde ulaşılmayandır,

- Lüks marka ürünlerinde algılanan değer çok önemlidir, bu nedenle tüketici deneyimi lüks olmayan markalara göre daha önemlidir.

Tablo 1. Literatürde Lüks ve Lüks Markaya Yönelik Yapılan Tanımlama Çalışmaları

\begin{tabular}{|c|c|c|}
\hline Adam Smith* & 1776 & $\begin{array}{l}\text { Tüketim mallarını dört kategoriye ayırmıştır; hayati (necessary) (hayatı } \\
\text { sürdürmek için), temel (normal büyüme ve refah için insanların ve top- } \\
\text { lumların refahı), refah (affluence) (büyüme ve refah için gerekli olmayan mal- } \\
\text { lar) ve lüks (sınırlı tedariği olan, üretimi çok zor olan veya çok pahalı mallar) }\end{array}$ \\
\hline McKinsey* & 1990 & $\begin{array}{l}\text { Lüks markalar, benzer işlevi olan ürünlerden daha yüksek fiyatlandırılması } \\
\text { tüketiciler tarafından kabullenilmiş olan markalardır. }\end{array}$ \\
\hline $\begin{array}{l}\text { Dubois ve } \\
\text { Duquese }\end{array}$ & 1993 & $\begin{array}{l}\text { Lüks, başkalarını etkilemek için, özellikle yüksek fiyatları ödeme ve zenginlik } \\
\text { gösterme arzuları içermektedir. }\end{array}$ \\
\hline Kapferer & 1997 & $\begin{array}{l}\text { Lüks markalar, kalite, güzellik, duygusallık, ayrıcalık, geçmiş, yüksek fiyat ve } \\
\text { eşsizlik özelliklerini içermektedir. }\end{array}$ \\
\hline $\begin{array}{l}\text { Nueno ve } \\
\text { Quelch }\end{array}$ & 1998 & $\begin{array}{l}\text { Lüks bir ürün, seçkin bir pazar için tasarlanmış bir eserdir. Latin alfabesindeki } \\
\text { "luxus"den türetilmiştir; maliyetten bağımsız olarak duyumların hoşgörüsü } \\
\text { anlamına gelir ve fiyata göre fonksiyonel fayda oranının düşük olduğu ve } \\
\text { maddi olmayan ve durumsal fayda oranlarının fiyat oranı yüksek olan } \\
\text { markalardır. }\end{array}$ \\
\hline $\begin{array}{l}\text { Phau ve } \\
\text { Prendergast }\end{array}$ & 2000 & $\begin{array}{l}\text { Lüks markalar dikkate çekicidir, tanınmış bir marka kimliğine sahiptir, } \\
\text { yüksek bir marka bilinirliği ve algılanan kalite sunarlar ve satış seviyelerini } \\
\text { ve müşteri sadakati ile muhafaza eder. }\end{array}$ \\
\hline $\begin{array}{l}\text { Dubois, } \\
\text { Laurent } \\
\text { ve } \\
\text { Czellar }\end{array}$ & 2001 & $\begin{array}{l}\text { Lüks, mükemmel kalite, yüksek fiyat, nadirlik ve eşsizlik, estetik ve çok duy- } \\
\text { ululuk, atalarının mirası ve kişisel geçmiş olarak altı unsur içermektedir. }\end{array}$ \\
\hline
\end{tabular}

\begin{tabular}{lcl}
\hline $\begin{array}{l}\text { Vickers ve } \\
\text { Renand }\end{array}$ & 2003 & $\begin{array}{l}\text { Birincil fonksiyonel boyutlara sahip lüks markalar, fiziksel ürünle ilgili dışa } \\
\text { yönelik tüketim ihtiyaçlarını çözmek için tasarlanmıştır. Deneyim, bir tüketi- } \\
\text { cinin duyu zevkini veren ürünleri tüketme arzusuyla ilişkilidir. Sembolik } \\
\text { etkileşimi yüksek olan lüks mallar, arzu edilen bir grup, rol veya kendi } \\
\text { imajyla ilişkilendirmek için tasarlanmıştır. }\end{array}$ \\
\hline $\begin{array}{l}\text { Prendergast } \\
\text { ve Wong }\end{array}$ & 2003 & $\begin{array}{l}\text { İyi kalite ve dizayn lüks ile bağdaştırılır. } \\
\text { Wetlaufer }\end{array}$ \\
& 2004 & $\begin{array}{l}\text { Lüks marka gelişiminde kurumsal kimliğin değeri, kültürün ve ruhun önemi } \\
\text { ve yaratıcı mükemmellik gereklidir. }\end{array}$ \\
\hline $\begin{array}{l}\text { Vigneron } \\
\text { ve Jonhson }\end{array}$ & 2004 & $\begin{array}{l}\text { Lüks marka prestij markasının bir formudur, prestijli markalar üst pazar, pre- } \\
\text { mium ve lüks olmak üzere üç seviyeye sahiptir ve lüksün derecesi dikkat } \\
\text { çekicilik, eşsizlik, kalite, hedonizm ve genişletilmiş benlik ile ölçülebilir. }\end{array}$
\end{tabular}




\begin{tabular}{|c|c|c|}
\hline Jackson & 2004 & $\begin{array}{l}\text { Lüks bir moda markası, fonksiyonellik dışında nedenlerle arzu edilir } \\
\text { kılınmak için birleştirilen ayrıcalık, premium fiyatlandırma, imaj ve statü ile } \\
\text { karakterize edilir. }\end{array}$ \\
\hline $\begin{array}{l}\text { Moore ve } \\
\text { Birtwistle }\end{array}$ & 2004 & $\begin{array}{l}\text { Lüks moda markalarında, imalatçının ürün, ciro, dağıtım ve premium fiyat- } \\
\text { landırma üzerinde sıkı denetime sahip olduğu, bütünlüğe sahip ikonik ürün } \\
\text { ve tasarımları vardır. }\end{array}$ \\
\hline $\begin{array}{l}\text { Silverstein, } \\
\text { Fiske ve } \\
\text { Butman }\end{array}$ & 2005 & $\begin{array}{l}\text { Lüks, kategorideki diğer mal ve hizmetlerden daha yüksek seviyede kalite, } \\
\text { zevk ve arzuya sahip ancak ulaşamayacak kadar pahalı olmayan ürünler için } \\
\text { gelişmiştir. }\end{array}$ \\
\hline Bever & 2005 & $\begin{array}{l}\text { Miras ve soyağacı, üslupta tutarlllık, kalite vaatleri, yerle ilişki, üretim } \\
\text { metodu ve ticari düşünceleri reddetmek gibi özgünlük nitelikleri lüks } \\
\text { markalara aktarllabilir }\end{array}$ \\
\hline
\end{tabular}

\begin{tabular}{lrl}
\hline Onkokwo & 2007 & $\begin{array}{l}\text { Lüks markalar son derece göze çarpan, farklı bir kimlik, küresel bir itibar, ye- } \\
\text { nilikçi, yaratıcı, eşsiz ve çekici ve premium fiyata sahip sıkı kontrollü bir } \\
\text { dağıtımla birinci sınıf kalite sunar. }\end{array}$ \\
\hline Dumoulin & 2007 & $\begin{array}{l}\text { Günümüzün lüks ifadesi, kişisel yaratıcllı̆̆ın, ifade kabiliyetinin, zekanın, } \\
\text { akışkanlığın ve tüm hepsinin kutlamasıdır. }\end{array}$ \\
\hline $\begin{array}{l}\text { Truong, } \\
\text { McColl } \\
\text { ve Kitchen }\end{array}$ & 2008 & $\begin{array}{l}\text { Yeni lüks, daha ulaşılabilir, daha değerlendirilebilir olarak yeni tüketiciler } \\
\text { tarafından hedef alındığından geleneksel lüksten farklılaşır. }\end{array}$ \\
\hline Thomas* & 2008 & $\begin{array}{l}\text { Çoğu lüks tanımlamanın çekirdeği elitizmdir, ancak bugün elitizm bir gerçek- } \\
\text { likten daha çok bir imajdır . }\end{array}$ \\
\hline $\begin{array}{l}\text { Atwal ve Wil- } 2009 \\
\text { liams }\end{array}$ & $\begin{array}{l}\text { Lüks, gelenekselin ötesine geçerek deneyimsel olmakta ve deneyimsel lüks } \\
\text { pazarlama tüketicinin markaya olan katılım ve bağlantı seviyesine göre, } \\
\text { eğlence, eğitim, kaçış ve estetik boyutları ile farkllllk göstermektedir. }\end{array}$ \\
\hline $\begin{array}{l}\text { Berthon, } \\
\text { Pitt, Parent } \\
\text { ve Berthon }\end{array}$ & 2009 & $\begin{array}{l}\text { Lüks, estetik olarak memnun eden, statü sağlayan, bir dereceye kadar } \\
\text { ayrıcalık veya nadirlik sunan, sosyal olarak gizem sağlayan ve bir markanın } \\
\text { fonksiyonel, deneyimsel ve sembolik unsurlarını kapsayan dikkat çekici bir } \\
\text { varlıktır. }\end{array}$
\end{tabular}

\begin{tabular}{lll}
\hline $\begin{array}{l}\text { Fionda } \\
\text { ve Moore }\end{array}$ & $2009 \begin{array}{l}\text { Marka lüksünün dokuz bileşeni vardır; net marka kimliği, lüks iletişim } \\
\text { stratejileri, ürün bütünlüğü, marka imzası, prestijli fiyat, ayrıcalık, tarih ya da } \\
\text { hikaye, küresel dağıtım ve lüks organizasyon kültürü. }\end{array}$ \\
\hline $\begin{array}{l}\text { Godey, Lagier } \\
\text { ve Pederzoli }\end{array}$ & $2009 \begin{array}{l}\text { Lüks mallar, ayrıcalık ile olmasa da seçicilik ile eşanlamlıdır ve lüksün tanımı } \\
\text { ve ölçümü son derece sübjektiftir. }\end{array}$ \\
\hline $\begin{array}{l}\text { Husic ve Cicic } \\
\text { Juggessur } \\
\text { ve Cohen }\end{array}$ & 2009 & $\begin{array}{l}\text { Marka lüksünün belirgin olumlu etkileri, marka imajının kendisi ve } \\
\text { kalitesidir. }\end{array}$ \\
& 2009 & $\begin{array}{l}\text { Yüksek moda markası, çoğunlukla prestij ve lüks markalarla eş anlamlı } \\
\text { olarak kullanılan, önemli ölçüde maddi olmayan değerleri olan ve tasarım, } \\
\text { kalite, statü ve modanın ön planda olduğu kabul edilen olumlu marka imaj- } \\
\text { larına sahip olan bir terimdir. }\end{array}$ \\
\hline $\begin{array}{l}\text { Kapferer } \\
\text { ve Bastien }\end{array}$ & $2009 \begin{array}{l}\text { Marka lüksünün iki yönü vardır; biri zevk (kişinin kendisi için lüks) diğeri ise } \\
\text { başarı sergilemektir (başkaları için lüks) ve lüks söz konusu olduğunda ben- } \\
\text { zersiz olmak, saygın olan şeydir. }\end{array}$ \\
\hline Keller & 2009 & $\begin{array}{l}\text { Marka lüksünün on karakteristiği vardır: premium imajı sürdürmek; soyut } \\
\text { marka çağrışmları yaratmak; kalite ile özdeşleşmek; logolar, semboller, ve }\end{array}$ \\
\hline
\end{tabular}




\begin{tabular}{|c|c|c|}
\hline & & $\begin{array}{l}\text { ambalaj dizaynı gibi soyut elementler; kişilikle bağlantılı ikincil çağrışımlar; } \\
\text { kontrollü dağıtım; premium fiyatlandırma; özenli yönetim; yaygın tanım; } \\
\text { yasal marka koruyucuları. }\end{array}$ \\
\hline $\begin{array}{l}\text { Kim, Kim } \\
\text { ve So Young }\end{array}$ & 2009 & $\begin{array}{l}\text { Lüks marka, algılanan dikkat çekicilik değeri, eşsizlik değeri, sosyal değer, } \\
\text { hedonik değer ve kalite değeri gibi çeşitli fiziksel ve psikolojik değerleri } \\
\text { kapsayan en üst düzey prestij markalarından biridir. }\end{array}$ \\
\hline $\begin{array}{l}\text { Tynan, } \\
\text { McKechnie } \\
\text { ve Chhuon }\end{array}$ & 2010 & $\begin{array}{l}\text { Lüks, sıradan bir sürekliliğin bir sonudur, sıradanlığın bittiği ve lüksün } \\
\text { başladığı yer tüketicilerin yargı derecesine bağlıdır. }\end{array}$ \\
\hline $\begin{array}{l}\text { Hung ve } \\
\text { diğ. }\end{array}$ & 2011 & $\begin{array}{l}\text { Lüks marka dikkat çeken, benzersiz ve dikkatle hazırlanmış markalı bir ürün- } \\
\text { dür. }\end{array}$ \\
\hline Kapferer* & 2012 & $\begin{array}{l}\text { Lüks, mutlak bir kavram olarak genellikle zengin ve güçlü bireylerin yaşam } \\
\text { görüntülerini uyandırır. }\end{array}$ \\
\hline $\begin{array}{l}\text { Megehee } \\
\text { ve Spake* }\end{array}$ & 2012 & $\begin{array}{l}\text { Lüks kavramı, kültür, var olma hali ve yaşam tarzının sonuçları ile } \\
\text { bağlantılıdır; lüks eşsiz, estetik, fonksiyonel ve pahalı mal-hizmet den- } \\
\text { eyimidir. }\end{array}$ \\
\hline
\end{tabular}

Kaynak: Miller ve Mills (2012)'den uyarlanmıştır, ${ }^{*}$ olan yazarlar bu çalışmada eklenmiştir.

Marka yönetimi olarak ele alındığında ise lüks marka yönetiminde, titiz bir dağıtım, güçlü bir marka imajı ve güçlü bir konumlandırma gerektiği görülmektedir.

Yapılan araştırmalarda Tablo 1'de görüldügüu gibi lüks markaların tüketici tarafından arzulanan belli başlı özellikleri konusunda görüş birliği ortaya çıkmaktadır (güzellik, nadirlik, kalite, yüksek fiyat, ...), aynı zamanda ürünü onaylayan, ilham veren bir markanın varlığı özelliklerin başlıcalarıdır. Bu bağlamda markalar, tüketiciler için ayrıcalık, kimlik, farkındalık ve algılanan kaliteyi uyandırma becerileri temelinde rekabet etmektedirler.

\section{Yöntem}

Mevcut çalışma modeli lüks markalara yönelik premium fiyat ödemeyi etkileyen unsurları belirlemeye çalışmaktadır. Bu araştırmada tüketicilerin lüks markalara pemium fiyatlar ödemelerini sağlayan etkenler olarak algılanan lüks marka değeri ve marka itibarı belirlenmiş, bu değişkenlerin etkisinin ölçülmesi amaçlanmıştır.

Araştırmada algılanan lüks marka değeri ve marka itibarı boyutları bağımsız değişken olarak ele alınmıştır. Literatürde algılanan lüks marka değeri alt boyutları olarak farklı değişkenler ele alınmakla birlikte bu çalışmada algılanan lüks marka değeri alt boyutlarında fonksiyonel değer, 
deneyimsel değer ve sembolik değer alt değişkenleri ele alınmıştır. Marka itibarı boyutuna lüks markalara yönelik yapılan çalışmalarda rastlanılmadığından bu açıdan literatüre katkıda bulunacağı öngörülmektedir.

Teorik kısımda anlatılan bilgilere dayanılarak ve araştırma amacina bağlı olarak, araştırmada test edilecek model ve hipotezlerin çalışma modeli üzerinde gösterimi Şekil 1'deki gibi oluşturulmuştur.

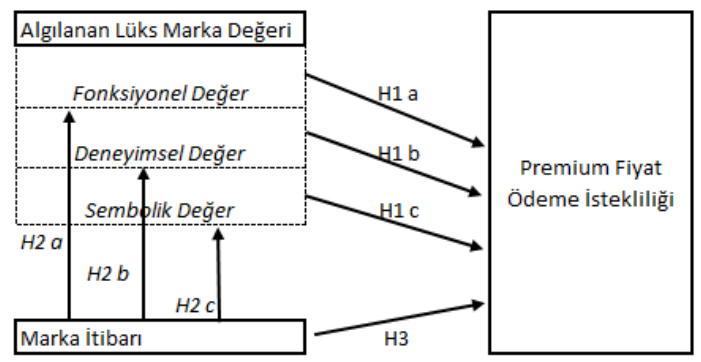

Şekil 1. Önerilen Araştırma Modeli ve Hipotezler

\section{Algilanan Değer Boyutu}

Çalışma kapsamında ele alınan araştırmalarda algılanan değerin araştırmacılar tarafından çokça çalışıldığı görülmektedir. Boyutları değişmekle birlikte özellikle fonksiyonel değer birçok çalışmada ele alınmıştır (Sweeney ve Soutar, 2001, s.211; Berthon ve diğ., 2009, s.47; Wiedmann, Henning ve Siebels, 2009, s.625; Hung ve diğ., 2011, s.457; Choo, Moon, Kim ve Yoon, 2012, s.86; Cheah, Phau, Chong ve Shimul, 2015, s.403; Chattalas ve Shukla, 2015, s.40; Lacroix ve Jolibert, 2017, s.205; Salehzadeh ve Pool, 2017, s.74).

Day (1990) çalışmasında algılanan değeri şu şekilde formulize etmiştir “Tüketicinin algıladığ1 faydalar - Tüketicinin algıladığ1 maliyetler = Algılanan müşteri değeri" (aktaran Lai, 1995, s.381). Alg1lanan değer genel olarak bir ürün satın alırken tüketicinin o üründen elde edeceğine inandığ fayda olarak tanımlanabilir (Kim, Ferrin ve Rao, 2008, s.547). Algilanan değer olgusu müşterilerin tercihleri ve değerlendirmeleri sonucunda meydana gelmektedir. Müşterilerin ürün satın alırken ve tüketirken beklentileri vardır ve beklentiler ne kadar karşılanırsa, ürünler için 
daha fazla değeri gözden çıkarmaya istekli olurlar (Bao, Bao ve Sheng, 2011, s.223).

Vigneron ve Johnson (1999) algılanan lüks marka değerini kişisel ve kişisel olmayan algılamalar olarak ikiye ayırmış, kişisel olmayan unsurları dikkat çekicilik, eşsizlik ve kalite; kişisel unsurları ise hedonik ve genişletilmiş benlik olarak belirtmiştir. Vigneron ve Johnson (2004), bir markanın algılanan lükslüğü ölçülebildiğinde yönetilebileceğini de önermektedirler. Çalışmalarında bir marka ile ilişkili tüketicilerin algilanan lüks düzeyini değerlendirebilmek için Marka Lüks Endeksini (BLI) geliştirmişler, algılanan lüks düzeyi için beş boyut belirlemişlerdir: dikkat çekicilik, eşsizlik, kalite, genişletilmiş benlik ve hedonizm. Berthon, Pitt, Parent ve Berthon (2009) lüks markaların değer bileşenleri olarak deneyimsel, sembolik ve fonksiyonel değerleri incelemişlerdir. Çalışmada üç değere ilişkin bulguları; fonksiyonel boyutu, lüks markanın maddi düzenlemesi olduğu yer, bir nesnenin temsil ettiği yerine malzeme dünyasında yaptığı şeylerin alanı olarak belirtilmiştir; deneyimsel boyut, bireysel öznel değer alanı; sembolik boyut ise, toplumsal kolektifin alanı olarak belirtilmiştir. Wiedmann, Henning ve Siebels (2009) lüks markaların algılanan değerini dört boyutta ele almıştır, fonksiyonel, bireysel (benlik için lüks), sosyal ve finansal değer. Çalışmada fonksiyonel değer, lüks ürünlerin sahip olduğu üstün performansı; bireysel değer hedonik yararlar ve beğenme meteryalizmini ; sosyal değerler, göze çarpmayı; finansal değer ise parasal bakış açısını belirtmiştir. Hung ve diğ. (2011) lüks marka algısını satın alma niyetini etkileyen bir değişken olarak ele almıştır. Choo, Moon, Kim ve Yoon (2012) tüketicilerin lüks marka değeri için dört boyut belirtmiştir, faydacı, hedonik, sembolik ve ekonomik. Sembolik değer yine de lüks tüketim üzerinde güçlü bir etkiye sahiptir. Kalite, kullanım, tasarım, tüketim bağlamı ve fiyat gibi belirli marka nitelikleriyle yakından ilişkili faydacı, hedonik ve ekonomik değerlerin aksine sembolik değer, bu özelliklerin herhangi birinden etkilenebilir olarak belirtilmiştir. Cheah, Phau, Chong ve Shimul (2015), lüks markaların fonksiyonel, deneyimsel ve sembolik değerlerinin marka şöhreti (brand prominence) ve lüks marka satın alma istekliliği üzerindeki etkisini incelemişlerdir. Lüks markaların sayılan değerleri ile ilişkilerini test ettikleri değişkenler üzerinde pozitif etki olduğunu bulmuşlardır. Chattalas ve Shukla (2015), lüks tüketime yönelik tüketicilerin algılanan 
değerin boyutlarını, sosyal değer, kişisel değer ve fonksiyonel değer olarak belirtmiştir. Fonksiyonel değer algılarının bir ürünün potansiyel olarak kullanılabilirliğine odaklanan faydacı tutumlardan etkilenebileceğini belirtmiştir. Salehzadeh ve Pool (2017), algılanan değerin üç boyutu olarak sosyal değer, kişisel değer ve fonksiyonel değeri ele almış, sayılan üç değişkenin satın alma niyeti üzerindeki etkisinin incelemiştir. Araştırmada algılanan değer boyutlarının satın alma niyetini doğrudan etkilediği sonucunu elde etmişlerdir.

Mevcut çalışmanın algılanan değer boyutunu ölçen hipotez Berthon ve diğ. (2009); Hung ve diğ. (2011); Cheah, Phau, Chong ve Shimul (2015) çalışmalara dayanarak oluşturulmuş, mevcut çalışmanın algılanan lüks marka değeri değişkeni etkenleri sembolik, fonksiyonel ve deneyimsel değer olarak ele alınmıştır. Değişkenlere ilişkin hipotezler aşağıdaki gibi geliştirilmiştir:

- H1: Algilanan lüks marka değerinin premium fiyat ödeme istekliliği üzerinde olumlu bir etkisi vardır.

- H1a: Fonksiyonel değer premium fiyat ödeme istekliliği üzerinde anlamlı bir etkiye sahiptir.

- H1b: Deneyimsel değer premium fiyat ödeme istekliliği üzerinde anlamlı bir etkiye sahiptir.

- H1c: Sembolik değer premium fiyat ödeme istekliliği üzerinde anlamlı bir etkiye sahiptir

\section{Marka İtibarı Boyutu}

Mevcut araştırma değişkenlerinden biri olan marka itibarının yapılan literatür taramasında daha önce değişken olarak ele alınmadığı görülmektedir. Çalışmada marka itibarı değişkeni Chandhuri'nin (2002) geliştirmiş olduğu ölçekler ile ölçülecektir. Orjinal ölçek 7'li Likert ile ölçülmüştür, mevcut çalışmada ise 5'li Likert ile ölçülecektir.

- $\mathrm{H}_{2}$ : Marka itibarının algılanan lüks marka değeri üzerinde olumlu bir etkisi vardir.

- $\mathrm{H}_{2 a}$ : Marka itibarı fonksiyonel değer üzerinde anlamlı bir etkiye sahiptir.

- $\mathrm{H}_{2 b}$ : Marka itibarı deneyimsel değer üzerinde anlamlı bir etkiye sahiptir. 
- $\mathrm{H}_{2 c}$ : Marka itibarı sembolik değer üzerinde anlamlı bir etkiye sahiptir.

- H3: Marka itibarının Premium fiyat ödeme istekliliği üzerinde anlamlı bir etkisi vardır.

\section{Premium fiyat ödeme istekliliğ i}

Premium fiyat ödeme istekliliği, müşterilerin tercih ettikleri markada, rakip ürünlerle karşılaştırıldığında benzer ürün özelliklerine daha fazla ödeme isteğinde bulunmalarıdır (Aaker, 1996, s.106; Netemeyer ve diğ, 2004, 211). Premium fiyat ödeme istekliliği bir lüks unsuru değildir ama lüksten kaynaklanan bir sonuç olarak belirtilmiştir (Miller ve Mills, 2012, s.1473). Miller ve Mills (2012) çalışmalarında marka lüksünün, marka değerinin ve marka uyumunun premium fiyat ödeme istekliliği üzerindekini etkisini incelemiştir. Godey ve diğ. (2016), sosyal medyadaki pazarlama çabalarının premium fiyat ödeme istekliliğine olan etkisini incelemiş ve aralarında önemli bir ilişki bulmuştur. Siu, Kwan ve Zeng. (2016), duygusal davranışın ve itibar kurtarmanın premium fiyat ödeme üzerindeki etkisini incelemişlerdir. Duygusal davranışın premium fiyat ödeme istekliliğgi üzerinde pozitif etkisi varken, saygınlığı korumanın premium fiyat ödeme istekliliği ile ilişkisi, bu konuda daha az olumlu duygusal tutumları bulunan tüketiciler için daha güçlüdür. Sreejesh, Sarkar ve Roy (2016), duygusal marka bağı ve bilişsel marka bağının premium fiyat ödeme niyetini üzerindeki etkisini incelemiş, aralarında önemli bir ilişki bulmuştur. Mevcut çalışmada ise premium fiyat ödeme istekliliğine etki eden bir diğer değişken olarak marka itibarı ele alınmış, hipotez aşağıdaki gibi oluşturulmuştur.

Çalışmada premium fiyat ödeme istekliliği değişkenin soruları Netemeyer ve diğ. (2004) çalışmasından alınmıştır. Orjina ölçek 7'li likert ile ölçülmüştür, mevcut çalışmada ise 5'li Likert ile ölçülecektir.

Araştırma değişkenlerinden algılanan lüks marka değeri ve premium fiyat ödeme istekliliği değişkenleri orijinal çalışmalarında 7'li likert ile ölçülmüştür. Marka itibarı değişkeni ise 5'li Likert ie ölçülmüştür. Mevcut çalışmada ise tüm değişkenler 5'li Likert ile ölçülecektir (1: kesinlikle 
katılmıyorum-5: kesinlikle katılıyorum). Ölçeklerin alındığı kaynaklar Tablo 2'de verilmiştir.

Tablo 2. Araştırma Değişkenleri

\begin{tabular}{lll}
\multicolumn{1}{c}{ Değişkenler } & \multicolumn{1}{c}{ Kaynaklar } & Orijinal Ölçek \\
\hline \hline Fonksiyonel Değer & Hung ve diğ. (2011) & 5'li Likert \\
Sembolik Değer & Hung ve diğ. (2011) & 5'li Likert \\
Deneyimsel Değer & Hung ve diğ. (2011) & 5'li Likert \\
Marka İtibarı & Chandhuri'nin (2002) & 7'li Likert \\
Premium Fiyat Ödeme İstekliliği & Netemeyer ve diğ. (2004) & 7'li Likert
\end{tabular}

Örnekleme yöntemi olarak, zaman ve bütçe kısıtı sebebiyle, kolayda örnekleme yöntemi kullanılmıştır. Bu nedenle sonuçlar üzerinden genelleme yapılamamaktadır. Veri toplama amacıyla online anket hazırlanmış ve cevaplayıcılara ulaştırılmıştır, 273 cevaplanmış anket elde edilmiştir.

\section{Bulgular}

Cevaplayıcılara ait demografik bilgiler Tablo 3.'te gösterilmektedir. Cevaplayıcıların özelliklerine bakıldığında, çoğunluğu kadınlardan $(\% 71,4)$ ve evlilerden (\%65) oluşmaktadır. Cevaplayıcıların yaş dağılımında en büyük grup 29-39 yaş aralığıdır (\%57,1). Eğitim seviyesinde en büyük grubu önlisans mezunları oluşturmaktadır $(\% 57,1)$. Hane gelirinde ise ağırlık 0-5000 TL gelir arasındadır $(\% 30,4)$.

Tablo 3. Demografik Özellikler

\begin{tabular}{|c|c|c|c|c|c|}
\hline Değişkenler & Frekans & Yüzde & Değişkenler & Frekans & Yüzde \\
\hline Cinsiyet & & & Eğitim Seviyesi & & \\
\hline Kadın & 195 & 71,4 & Lise & 41 & 15 \\
\hline \multirow[t]{2}{*}{ Erkek } & 78 & 28,6 & Önlisans & 156 & 57,1 \\
\hline & & & Lisans & 48 & 17,6 \\
\hline Medeni Durum & & & Yüksek Lisans & 13 & 4,8 \\
\hline Evli & 180 & 65,9 & Doktora & 14 & 5,1 \\
\hline \multirow[t]{2}{*}{ Bekar } & 93 & 34,1 & & & \\
\hline & & & Hane Gelir Sevi & & \\
\hline Yaş & & & $<5.000$ & 83 & 30,4 \\
\hline $18-28$ & 41 & 15 & $5.001-7.500$ & 59 & 21,6 \\
\hline $29-39$ & 156 & 57,1 & 7.501-10.000 & 40 & 14,7 \\
\hline $40-50$ & 48 & 17,6 & $10.001-15.000$ & 47 & 17,2 \\
\hline $51-61$ & 13 & 4,8 & $15.000<$ & 44 & 16,1 \\
\hline $62-70$ & 14 & 5,1 & & & \\
\hline
\end{tabular}


Araştırma modelindeki değişkenlerin tek boyutlu olup olmadığının, olmaması durumunda kaç boyut altında toplandığının belirlenmesi amacıyla faktör analizinden faydalanılmıştır.

Aşağıdaki Tablo 4'de görüleceği üzere, faktör analizi için gerçekleştirilen KMO değeri 0,903 ve Bartlett testi sonucu ise 0,000 olarak belirlenmiştir. $\mathrm{Bu}$ durum verilerin faktör analizi için yetkinliğine işaret etmektedir.

Tablo 4: KMO and Bartlett's Test

\begin{tabular}{lll}
\hline Kaiser-Meyer-Olkin Measure of Sampling Adequacy. &, 903 \\
Bartlett's Test of Sphericity & Approx. Chi-Square & 2877,930 \\
& df & 190 \\
& Sig. &, 000 \\
\hline
\end{tabular}

Ölçeklerin güvenilirliği için, güvenilirliğin incelenmesinde en yaygın olarak kullanılan yöntem olan Cronbach's Alpha Katsayısı kullanılmıştır. Ölçeklerin güvenilirlikleri, fonksiyonel değer: $\alpha=0,804$ (4 ifade); deneyimsel değer: $\alpha=0,870$ (4 ifade), sembolik değer: $\alpha=0,654$ ( 3 ifade); marka itibarı: $\alpha: 0,714$ (5 ifade); premium fiyat ödeme istekliliği: $\alpha: 0,797$ (3 ifade)'dir.

Tüm veriler faktör analizine tabi tutulmuştur. Faktör analizi sonuçları Tablo 5'te verilmiştir. Deneyimsel Değer boyutunun "Lüks markanın ürünü nadirdir" ifadesi düşük faktör yükü nedeniyle analiz dışında bırakılmıştır. Tekrarlanan faktör analizi sonuçlarına göre modeldeki değişkenleri beş faktör altında toplanmaktadır. Bu faktörler fonksiyonel değer, deneyimsel değer, sembolik değer, marka itibarı ve premium fiyat ödeme istekliliğidir. Analiz sonucunda elde edilen faktörler toplam varyansın \%67,474'ünü açıklamaktadır. 
Tablo 5: Faktör Analizi Sonuçları

\begin{tabular}{|c|c|c|c|c|c|}
\hline & $\begin{array}{l}\text { Faktör } \\
\text { Adı }\end{array}$ & İfade & $\begin{array}{l}\text { Faktör } \\
\text { Yükleri }\end{array}$ & $\begin{array}{l}\text { Faktör } \\
\text { Açıklayıcılığı }\end{array}$ & $\begin{array}{l}\text { Güvenilirlik } \\
\text { (Cronbach's } \\
\text { Alpha) }\end{array}$ \\
\hline F1 & $\begin{array}{l}\text { Fonksiyo- } \\
\text { nel Değer }\end{array}$ & $\begin{array}{l}\text { Lüks markanın ürünü el } \\
\text { yapımıdır }\end{array}$ & 0,755 & \multirow{4}{*}{15,692} & \multirow{4}{*}{0,804} \\
\hline F2 & & $\begin{array}{l}\text { Lüks markanın ürünü en iyi } \\
\text { kaliteye sahiptir }\end{array}$ & 0,591 & & \\
\hline F3 & & $\begin{array}{l}\text { Lüks markasının ürünü sofis- } \\
\text { tikedir }\end{array}$ & 0,656 & & \\
\hline F4 & & $\begin{array}{l}\text { Lüks markanın ürünü üstün ni- } \\
\text { teliklidir }\end{array}$ & 0,700 & & \\
\hline D1 & \multirow{4}{*}{$\begin{array}{l}\text { Deneyim- } \\
\text { sel } \\
\text { Değer }\end{array}$} & $\begin{array}{l}\text { Lüks markanın ürünü } \\
\text { kıymetlidir }\end{array}$ & 0,795 & \multirow{4}{*}{16,718} & \multirow{4}{*}{0,870} \\
\hline D3 & & Lüks markanın ürünü çekicidir & 0,772 & & \\
\hline D4 & & $\begin{array}{l}\text { Lüks markanın ürünü etkileyici- } \\
\text { dir }\end{array}$ & 0,838 & & \\
\hline D5 & & Lüks markanın ürünü çarpıcıdır & 0,815 & & \\
\hline S1 & \multirow[t]{3}{*}{$\begin{array}{l}\text { Sembolik } \\
\text { Değer }\end{array}$} & $\begin{array}{l}\text { Lüks markanın ürünü dikkat } \\
\text { çekicidir }\end{array}$ & 0,742 & \multirow{3}{*}{12,832} & \multirow{3}{*}{0,654} \\
\hline S2 & & Lüks markanın ürünü pahalıdır & 0,661 & & \\
\hline S3 & & $\begin{array}{l}\text { Lüks markanın ürünü zengin } \\
\text { gösterir }\end{array}$ & 0,684 & & \\
\hline M1 & \multirow{5}{*}{$\begin{array}{l}\text { Marka } \\
\text { İtibarı }\end{array}$} & Lüks marka statü sahibidir & 0,872 & \multirow{5}{*}{9,959} & \multirow{5}{*}{0,714} \\
\hline M2 & & Lüks markanın itibarı iyidir & 0,893 & & \\
\hline M3 & & $\begin{array}{l}\text { Lüks marka iyi bilinen bir } \\
\text { markadır }\end{array}$ & 0,862 & & \\
\hline M4 & & $\begin{array}{l}\text { Lüks marka popüler bir } \\
\text { markadır }\end{array}$ & 0,852 & & \\
\hline M5 & & $\begin{array}{l}\text { Lüks marka saygı gören bir } \\
\text { markadır }\end{array}$ & 0,544 & & \\
\hline P1 & \multirow{3}{*}{$\begin{array}{l}\text { Premium } \\
\text { Fiyat } \\
\text { Ödeme } \\
\text { İstekliliği }\end{array}$} & $\begin{array}{l}\text { Lüks markanın fiyatını biraz } \\
\text { yükseltmesi başka markaya } \\
\text { geçmeme neden olmaz }\end{array}$ & 0,677 & \multirow{3}{*}{12,273} & \multirow{3}{*}{0,797} \\
\hline P2 & & $\begin{array}{l}\text { Lüks marka ürünlerine, diğer } \\
\text { markaların ürünlerine göre daha } \\
\text { yüksek fiyat ödeyebilirim }\end{array}$ & 0,812 & & \\
\hline P3 & & $\begin{array}{l}\text { Lüks marka ürünlerine, diğer } \\
\text { markaların ürünlerine göre çok } \\
\text { daha yüksek fiyat ödeyebilirim }\end{array}$ & 0,828 & & \\
\hline
\end{tabular}

Araştırmada yer alan hipotezlerin test edilmesi amacıyla çoklu regresyon analizinden faydalanılmıştır. Regresyondan önce değişkenler arasındaki ilişkilerin tespit edilmesi amaciyla korelasyon analizi gerçekleştirilmiştir. İlgili sonuçlar aşağıdaki Tablo 6'da görülmektedir. 
Tablo 6: Araştırma Modelinde Yer Alan Hipotezlere Ait Korelasyon Analizi

\begin{tabular}{|c|c|c|c|c|c|c|}
\hline & & Fonksiyonel & $\begin{array}{l}\text { Deneyim- } \\
\text { sel }\end{array}$ & Sembolik & $\begin{array}{l}\text { Marka } \\
\text { itibari }\end{array}$ & Premium \\
\hline \multirow[t]{3}{*}{ Fonksiyonel } & $\begin{array}{l}\text { Pearson Cor- } \\
\text { relation }\end{array}$ & 1 &, $615\left(^{* *}\right)$ &, $\left.4388^{* *}\right)$ &, $397\left(^{* *}\right)$ & $\left.4988^{* *}\right)$ \\
\hline & Sig. (2-tailed) & & ,000 & , 000 & ,000 & ,000 \\
\hline & $\mathrm{N}$ & 273 & 273 & 273 & 273 & 273 \\
\hline \multirow[t]{3}{*}{ Deneyimsel } & $\begin{array}{l}\text { Pearson Cor- } \\
\text { relation }\end{array}$ &, $\left.615^{* *}\right)$ & 1 &, $\left.6066^{* *}\right)$ &, $544\left(^{* *}\right)$ &, $512\left({ }^{(* *}\right)$ \\
\hline & Sig. (2-tailed) & ,000 & & , 000 & , 000 & ,000 \\
\hline & $\mathrm{N}$ & 273 & 273 & 273 & 273 & 273 \\
\hline \multirow[t]{3}{*}{ Sembolik } & $\begin{array}{l}\text { Pearson Cor- } \\
\text { relation }\end{array}$ &, $\left.4388^{* *}\right)$ &, $\left.6066^{* *}\right)$ & 1 &, $\left.6566^{(* *}\right)$ &, $357\left(^{* *}\right)$ \\
\hline & Sig. (2-tailed) & ,000 & , 000 & & , 000 & ,000 \\
\hline & $\mathrm{N}$ & 273 & 273 & 273 & 273 & 273 \\
\hline \multirow[t]{3}{*}{ Markaitibari } & $\begin{array}{l}\text { Pearson Cor- } \\
\text { relation }\end{array}$ &, $397\left(^{* *}\right)$ &, $\left.5444^{* *}\right)$ &, $\left.6566^{* *}\right)$ & 1 &, $\left.4199^{* *}\right)$ \\
\hline & Sig. (2-tailed) & ,000 & ,000 & , 000 & & ,000 \\
\hline & $\mathrm{N}$ & 273 & 273 & 273 & 273 & 273 \\
\hline \multirow[t]{3}{*}{ Premium } & $\begin{array}{l}\text { Pearson Cor- } \\
\text { relation }\end{array}$ &, $498\left(^{* *}\right)$ &, $512\left(^{* *}\right)$ &, $\left.3577^{* *}\right)$ &, $419\left(^{* *}\right)$ & 1 \\
\hline & Sig. (2-tailed) & ,000 & ,000 & ,000 & ,000 & \\
\hline & $\mathrm{N}$ & 273 & 273 & 273 & 273 & 273 \\
\hline
\end{tabular}

** Correlation is significant at the 0.01 level (2-tailed).

Tabloya göre değişkenler arasında anlamlı ilişkiler bulunmaktadır. Özellikle bağımsız değişkenlerin birbirleri ile ilişkilerinin anlamlı düzeyde olması beklenirken bu ilişki düzeyinin çok yüksek olması çoklu bağıntıya işaret edebilecektir. Ancak burada da görüldügü gibi özellikle bağımsız değişkenler arasındaki anlamlı ilişkinin düzeyi \%70'in altındadır. Bu herhangi bir çoklu bağıntı olmadığının kanıtıdır.

Hipotezlerin analizi için yapılan regresyon analizi sonuçları Tablo 7' de gösterilmektedir. 
Tablo 7: Araştırma Modelinde Yer Alan Hipotezlere Ait Regresyon Analizi Sonuçları

\begin{tabular}{lllll}
\hline Bağımlı Değişken & Bağımsız Değişken & Beta & $\mathrm{p}$ & \multicolumn{1}{c}{$\mathrm{R}^{2}$} \\
\hline \multirow{3}{*}{ Premium Fiyat Ödeme İstekliliği } & Fonksiyonel Değer & 0,273 & 0,000 & 0,344 \\
\cline { 2 - 5 } & Deneyimsel Değer & 0,314 & 0,000 & 0,344 \\
\cline { 2 - 5 } & Sembolik değer & $-0,133$ & 0,091 & 0,344 \\
\cline { 2 - 5 } & Marka İtibarı & 0,227 & 0,001 & 0,344 \\
\hline Fonksiyonel Değer & Marka İtibarı & 0,397 & 0,000 & 0,158 \\
\hline Deneyimsel Değer & Marka İtibarı & 0,544 & 0,000 & 0,296 \\
\hline Sembolik değer & Marka İtibarı & 0,656 & 0,000 & 0,430 \\
\hline
\end{tabular}

Algılanan lüks marka değer boyutları ile (H1a, H1b ve H1c) marka itibarı boyutunun (H3) test edilmesi amacıyla yapılan çoklu regresyon analizine göre model anlamlıdır. İlgili Beta ve sig değerleri Tablo 7' de özetlenmektedir. Yukarıdaki tablodan görüleceği gibi, fonksiyonel değer, deneyimsel değer ve marka itibarının premium fiyat ödeme istekliliği üzerinde anlamlı etkisi vardır. Bunun yanında sembolik değerin Premium fiyat ödeme istekliliği üzerinde herhangi bir anlamlı etkisine rastlanmamıştır. Bu durumda $\mathrm{H} 1 \mathrm{a}, \mathrm{H} 1 \mathrm{~b}$ ve $\mathrm{H} 3$ kabul edilirken $\mathrm{H} 1 \mathrm{c}$ reddedilmiştir. Beta değerlerine bakıldığında premium fiyat ödeme istekliliği üzerinde en çok etkisi bulunan değişkenlerin sırasıyla deneyimsel değer, fonksiyonel değer ve marka itibarı olduğu sonuçları görülmektedir. Bu değişkenlerin Premium fiyat ödeme istekliliğini açıklama/etkileme oranı \%34,4'tür ( $\left.\mathrm{R}^{2}\right)$. H2a, H2b ve H2c' nin test edilmesi amaciyla basit doğrusal regresyon analizinden faydalanılmıştır. Marka itibarının fonksiyonel değer üzerinde anlamlı bir etkisi bulunmaktadır. Bu etki \%15,8 $\left(\mathrm{R}^{2}\right)$ düzeyindedir. Bu durumda H2a kabul edilmiştir. Marka itibarının deneyimsel değer üzerindeki etkisini belirlemek amacıyla yapılan basit doğrusal regresyon analizi sonuçlarında model anlamlıdır ve marka itibarının deneyimsel değer üzerinde anlamlı bir etkisi bulunmaktadır. Diğer bir değişle, H2b kabul edilmiştir. Etkinin düzeyi ise \%29,6 ( $\left.{ }^{2}\right)$ olarak belirlenmiştir. Son olarak marka itibarının sembolik değer üzerindeki etkisini ölçmek amacıyla basit doğrulsal regresyon analizinden faydalanılmıştır. Yukarıdaki tabloda özetlendiği gibi, marka itibarının sembolik değer üzerinde anlamlı bir etkisi bulunmaktadır. Son hipotez 
olan H2c de kabul edilmiştir. Tablo 7'de de görüldüğü gibi, marka itibarı sembolik değeri \%43,0 $\left(R^{2}\right)$ gibi yüksek bir oranda etkilemektedir.

\section{Sonuç}

Pazarlama stratejilerinin temel stratejilerinde olan konumlandırma, tüketicilere onlara çözümler sunan işletmeler arasında tercih yapmak için neden sunma çabalarından oluşmaktadır. Lüks markalar için de lüks ve kaliteli olmak tüketici algısında yeterli olmayınca işletmeler farklı değerler sunma arayışı içine girmişlerdir.

Tüketiciler satın alma aşamasında ürün veya hizmetten farklı değerler beklemektedir. Bu çalışma tüketicilerin lüks ürünlere yüksek fiyat ödeme karşılığında, lüks markalardan bekledikleri algılanan fonksiyonel, deneyimsel ve sembolik değerler ele alınmıştır. Ayrıca yapılan kısıtlı literatür araştırmasında tüketicilerin yüksek fiyat ödemesine olan etkisine bakılmayan bir kavram olarak marka itibarının tüketicilerin algısına olan etkisi de incelenmiştir. Araştırmada tesadüfi örnekleme yöntemlerinde kolayda örnekleme yönteminin seçilmiş olması sonuçlarda genelleme yapılmasını sağlayamamakla birlikte modeldeki değişkenler ile farklı bir bakış açısı sunmaktadır.

Araştırma sonuçları literatürde yer alan çalışmalar ile karşılaştırıldığında; Hung ve diğ. (2011) lüks marka alımının deneyimsel ve işlevsel yönleri satın alma niyeti ile pozitif yönde ilişkili olduğunu ancak sembolik değer ile böyle bir ilişki olmadığını belirtmiştir. Choo, Moon, Kim ve Yoon (2012) lüks müşteri değeri çalışmalarında işlevsel, hedonik, sembolik ve ekonomik değerlerin arasında ilişki olduğunu belirtmiştir. Salehzadeh ve Pool (2017) marka tutumunun algilanan değeri ve onun üç boyutunu (sosyal değer, kişisel değer ve işlevsel değer) olumlu etkilediğini algılanan değerlerin satın alma niyetinin direkt etkileyicileri olduğunu belirtmiştir. Mevcut çalışma analizi sonucunda birçok çalışmada yer aldığı gibi algılanan fonksiyonel değerin ve deneyimsel değerin Premium fiyat ödeme üzerinde anlamlı bir etkisi olduğu bulunmuştur. Literatüre katkı yapacağı düşünülen marka itibarının algılanan lüks marka değerlerine ve Premium fiyat ödeme üzerine anlamlı bir etkisinin olması da beklenen bir sonuç olarak araştırmada elde edilmiştir. Çalışmanın bu yönüyle de literatüre katkı yapacağı düşünülmektedir. 
Çalışma, pazarlama profesyonelleri için özellikle yüksek fiyat içeren ürünlerde marka yönetiminin ne kadar önemli olduğunu, tüketici algılarını etkileyen unsurların çok yönlü olarak düşünülüp yönetilmesinin gerektiğini vurgulamaktadır. Pazarlama yöneticilerinin markalarının itibar yönetimi için yaptıkları çalışmaların, tüketicilerin satın alma anındaki kararlarına olan etkisi işletme amaçlarına ulaşılmada önemli bir nokta olarak görülmektedir. 


\title{
EXTENDED ABSTRACT
}

\section{The Effect of Perceived Luxury Brand Value and Brand Reputation on Willingness to Pay Price Premium}

\author{
* \\ Özge Habiboğlu - Aypar Uslu \\ Namık Kemal Üniversitesi- Marmara Üniversitesi
}

Differentiation is one of the most important strategies for companies to distinguish their propositions from their competitors. The success in the differentiation of the company makes it more competitive than its competitors. The most important point to be emphasized here is that consumer's perception about differences which should be in the same way. Luxury brands, which are an important part of brand management, are special and high price brands in return for certain benefits they offer. The benefits offered are the result of significant marketing efforts, but they can be as strong as perceived by consumers. The present study investigated the level of perception of the benefits offered by companies against price premium by consumers and the effect of the brand's reputation on this perception level. There are studies examining the effect of perceived value of brands on price premium in the literature, and the present study has tried to contribute to the literature with the brand reputation variable. For this purpose, the existence of the relationships with the primary data collected were examined.

The oldest sensations about luxury products are located in the middle of the 17th century. Luxury products which belong to different categories in human history have become master craftsmanship with the rise of world trade in the 19th and early 20th centuries. With the development of industry and production, by mass production luxury have become elaborately crafted symbols by the brand to invoke the world of dreams, images, signs and motifs, beyond craftsmen (Berthon, Pitt, Parent, Berthon, 2009, p. 45). Since Adam Smith (1776), the oldest definition available, many studies on luxury goods have been conducted in the literature and definition studies have been carried out for the concept. Although common consensus cannot be reached, common features in the definitions are 
noteworthy. Luxury brands are high-priced goods (Smith, 1776; Mc Kinsey, 1990; Dubois and Duquese, 1993; Kapferer, 1997; Dubois, Laurent and Czellar, 2001;). Luxury goods provide uniqueness and attention to the owner, (Kapferer, 1997; Dubois, Laurent and Czellar, 2001; Vigneron and Jonhson, 2004; Onkokwo, 2007; Kim, Kim and So Young, 2009; Hung et al., 2011; Megehee and Spake, 2012). Luxury goods have high quality, wellknown brand identity, positive and high brand experience (Phau and Prendergast, 2000; Vickers and Renand, 2003; Prendergast and Wong, 2003; Atwal and Williams, 2009; Berthon et al., 2009; Megehee and Spake, 2012).

The present study attempts to identify the factors that affect price premium payment for luxury brands. The study determined perceived luxury brand value and brand reputation, as the factors enabling consumers to pay price pemium to luxury brands, effect of these variables was measured. In the research, perceived luxury brand value and brand reputation dimensions were considered as independent variables. In the literature, the perceived benefits of brands have been handled differently by many researchers (Day, 1990; Vigneron and Johnson, 1999; Berthon, Pitt, Parent and Berthon, 2009; Wiedmann, Henning and Siebels, 2009; Choo, Moon, Kim and Yoon, 2012). Cheah, Phau, Chong and Shimul, 2015; Chattalas and Shukla, 2015; Salehzadeh and Pool, 2017; Hung et al., 2011). The present study perceived values were reported by Berthon et al. (2009); Hung et al. (2011); Cheah, Phau, Chong and Shimul (2015) were created based on the studies and perceived factors of luxury brand value were considered as symbolic, functional and experiential value. In the literature review, one of the current research variables, brand reputation, was not previously considered as a variable in luxury brand management. In this study, the brand reputation variable will be measured by the scales developed by Chandhuri (2002). The willingness to pay price premium is that customers want to pay more for similar product features compared to competing products in their preferred brand (Aaker, 1996, p.106; Netemeyer et al., 2004, 211). In the study, the questions of the willingness to pay price premium variable were determined by Netemeyer et al. (2004). The hypotheses based on the literature are as follows:

- H1: The perceived luxury brand value has a positive effect on the willingness to pay price premium. 
- H2: Brand reputation has a positive impact on perceived luxury brand value.

- H3: Brand reputation has a significant impact of on willingness to pay price premium.

All variables were measured with 5-point Likert form. (1: Absolutely disagree-5: Absolutely agree). Convenience sampling method was used due to time and budget constraints. Therefore, generalization cannot be made on the results. For the purpose of data collection, an online questionnaire was prepared and delivered to the respondents. 273 answered questionnaires were obtained.

As a result of the research, functional value, experiential value and brand reputation have a significant effect on the willingness to pay price premium, however, there isn't any significant effect of symbolic value on the willingness to pay premium price was found. In this case, $\mathrm{H} 1 \mathrm{a}, \mathrm{H} 1 \mathrm{~b}$ and $\mathrm{H} 3$ were accepted and $\mathrm{H} 1 \mathrm{c}$ was rejected. It is seen that the most effective variables are experiential value, functional value and brand reputation on willingness to pay price premium. $\mathrm{H} 2 \mathrm{a}, \mathrm{H} 2 \mathrm{~b}$ and $\mathrm{H} 2 \mathrm{c}$ were accepted as the effect of brand reputation on perceived values.

- H1a: Functional value has a significant effect on the willingness to pay price premium. ACCEPTED

- H1b: Experiential value has a significant impact on the willingness to pay price premium. ACCEPTED

- H1c: The symbolic value has a significant impact on the willingness to pay price premium. REJECTED

- H2a: Brand reputation has a significant impact on functional value. ACCEPTED

- H2b: Brand reputation has a significant impact on experiential value. ACCEPTED

- H2c: Brand reputation has a significant impact on the symbolic value. ACCEPTED

- H3: Significant impact of brand reputation on willingness to pay price premium. ACCEPTED

According the results of the research were compared with the literature; Hung et al. (2011) stated that the experiential and functional aspects of luxury brand purchase were positively related to intention to purchase, but not with symbolic value. Choo, Moon, Kim and Yoon (2012) stated 
that there is a relationship between functional, hedonic, symbolic and economic values in luxury customer value studies. Salehzadeh and Pool (2017) stated that brand attitude positively affects the perceived value and its three dimensions (social value, personal value and functional value) and perceived values are the direct influencers of purchasing intention. As a result of the present study analysis, it has been found that perceived functional value and experiential value have a significant effect on Premium price payment as it is included in many studies. It is expected that the brand reputation that will contribute to the literature will have a significant effect on perceived luxury brand values and premium price payment. This aspect of the study is thought to contribute to the literature.

The study emphasizes the importance of brand management for marketing professionals, especially in high price products, and the factors that affect consumer perceptions should be considered and managed in a multi-faceted way. The effect of marketing managers 'efforts on reputation management of their brands on consumers' decisions at the time of purchase is seen as an important point in achieving business objectives.

\section{Kaynakça / References}

Aaker, D. A. (1996). Measuring brand equity across products and markets. California Management Review, 38, 102-120.

Atwal, G. ve Williams, A. (2009). Luxury brand marketing-the experience is everything. Journal of Brand Management, 16, 338-346.

Audrin, C., Brosch, T. C. J. ve Sander, D. (2017). When Symbolism overtakes quality: Materialists consumers disregard product quality when faced with luxury brands. Journal of Economic Psychology, 61, 115-123.

Bao, Y., Bao, Y. ve Sheng, S. (2011). Motivating purchase of private brands: Effects of store image, product signatureness and quality variation. Journal of Business Research, 64, 220-226.

Berthon, P., Pitt, L., Parent, M. ve Berthon, J.-P. (2009). Aesthetics and Ephemerality: Observing and preserving the luxury brand. California Management Review, 52, 45-66.

Beverland, M. B. (2004). Uncovering "theories in use": Building luxur wine brands. European Journal of Marketing, 38, 446-466. 
Chattalas, M. ve Shukla, P. (2015). Impact of value perceptions on luxury purchase intensions: a Developed market comparison. Luxury Research Journal, 1, 40-57.

Chaudhuri, A. (2002). How brand reputation Affects the advertising-brand equity link. Journal of Advertising Research, 42, 33-43.

Cheah, I., Phau, I., Chong, C. ve Shimul, A. S. (2015). Antecedents and outcomes of brand prominence on willingness to buy luxury brands. Journal of Fashion Marketing and Management, 19, 402-415.

Choo, H. J., Moon, H., Kim, H. ve Yoon, N. (2012). Luxury customer value. Journal of Fashion Marketing and Management, 16, 81-101.

Christodoulides, G., Michaelidou, N. ve Li, C. H. (2009). Mesasuring perceived brand luxury: An evaluation of the BLI scale. Brand Management, 16, 395-405.

Day, G., S. (1990), Market driven strategy. New York, NY: Free Press

Dubois, B., Czellar, S. ve Laurent, G. (2005). Consumer segments based on attitudes toward luxury: Empirical evidence from twenty countries. Marketing Letters, 16, 115-128.

Dubois, B. ve Duquense, P. (1993). The market for luxury goods: Income versus culture. Marketing and Research Today, 27, 25-44.

Dubois, B., Laurent, G. ve Czellar, S. (2001). Consumer rapport to luxury: Analyzing complex and ambivalent attitudes. France: HEC School of Management.

Dumoulin (2007). What is today's definition of luxury. Admap, 42(3), 27-30.

Fionda, A. M. ve Moore, C. M. (2009). The Anatomy of the Luxury fashion brand. Brand Management, 16, 347-363.

Fuchs, C., Prandelli, E., Schreier, M. ve Dahl, D. W. (2013). All that is users might not be gold: how labeling products as user designed backfires in the context of luxury fashion brands. Journal of Marketing, 77, 75-91.

Gil, L. A., Kwon, K.-N., Good, L. K. ve Johnson, L. W. (2012). Impact of Self on attitudes toward luxury brands among teens. Journal of Business Research, 65, 1425-1433.

Godey, B., Lagier, J. ve Pederzoli, D. (2009). A Measurement Scale of "aesthetic style" applied to luxury goods stores. International Journal of Retail and Distribution Management, 37, 527-537. 
Godey, B., Pederzoli, D., Aiello, G., Donvito, R., Wiedmann, K. P., ve Hennigs, N. (2013). A cross-cultural exploratory content analysis of the perception of luxury from six countries. Journal of Product ve Brand Management, 22, 229-237.

Godey, B., Manthiou, A., Pederzoli, D., Rokka, J., Aiello, G., Donvito, R., ve Singh, R. (2016). Social media marketing efforts of luxury brands: influence on brand equity and consumer behavior. Journal Of Business Research, 69, 5833-5841.

Haine, K. ve Phan, M. (2011). Trading-up Mass-market goods to luxury product. Australasian Marketing Journal, 19, 108-114.

Hassan, S. ve Mehmedovic, M. H. Duverger, P. (2015). Retaining the allure of luxury brands during an economic downturn. Journal of Fashion Marketing and Management, 19, 416-429.

Hudders, L., Pandelaere, M. ve Vyncke, P. (2013). Consumer meaning making the meaning of luxury brands in a democratised luxury world. International Journal of Marketing Research, 55, 391-412.

Hung, K., Chen, A., Peng, N., Hackley, C., Tiwsakuş, R. A. ve Chou, C. (2011). Antecedents of luxury brand purchase intention. Journal of Product and Brand Management, 20, 457-467.

Husic, M. ve Cicic, M. (2009). Luxury consumption factors. Journal of Fashion Marketing and Management, 13, 231-245.

Jain, V., ve Schultz, D. E. (2019). How digital platforms influence luxury purchase behavior in India. Journal of Marketing Communications, 25, 4164.

Juggessur J, ve Cohen G. (2009). Is fashion promoting counterfeit brands? Journal of Brand Management, 16, 383-394.

Kapferer, J.-N. (1998). Why Are we seduced by luxury brands. Journal of Brand Management, 6, 44-4.

Kapferer, J. N. (1997). Managing luxury brands. Journal of Brand Management, $4,251-260$.

Kapferer, J. N. (2012). Abundant rarity: The key to luxury growth. Business Horizons, 55, 453-462.

Kapferer, J. N. ve Bastien, V. (2009). The specifity of luxury management: Turning marketing upside down. Joyrnal of Brand Management, 16, 311-322. 
Kapferer, J.-N. ve Valette-Florence, P. (2016). Beyond rarity: the paths of luxury desire. How luxury brands grow yet remain desirable. Journal of Product and Brand Management, 25, 120-133.

Kapferer, J.-N. ve Laurent, G. (2016). Where do consumers think luxury begins? A Study of perceived minimum price for 21 luxury goods in 7 countries. Journal of Business Research. 69, 332-340

Keller, K. L. (2009). Managing the growth tradeoff: Challenges and opportunities in luxury branding. Journal of Brand Management, 16, 290-301.

Kemp, S. (1998). Perceiving luxury and necessity. Journal of Economic Psychology, 19, 591-606.

Kim, D. J., Ferrin, D. L. ve Rao, H. R. (2008). A Trust-based consumer decision making model in electronic commerce: The role of trust, perceived risk and their antecedents. Decision Support Systems, 44, 544-564.

Kim, A. Kim, G. ve So Young, S. (2009). Conjoint analysis for luxury brand outlet malls in Korea with consideration of customer lifetime value. Expert Sistems with Applicaitons, 36, 922-932.

Kim, K. H., Ko, E., Xu, B. ve Han, Y. (2012). Increasing customer equity of luxury fashion brands through nurturing consumer attitude. Journal of Business Research, 65, 1495-1499.

Lacroix, C. ve Jolibert, A. (2017). Mediational role of perceived personal legacy value between consumer agentic generativity and attitudes/buying intensions toward luxury brands. Journal of Business Research, 77, 203211.

Lai, A. W., (1995). Consumer values, product benefits and customer value: a consumption behavior approach. Advances in Cosnumer Research, 22, 381-388

Lee, E., Edwards, S. M., Youn, S. ve Yun, T. (2018). Understanding the moderating effect of motivational values on young consumers' responses to luxury brands: A cross cultural study of South Korea and the USA. Journal of Marketing Communications,24, 103-124

Lee, J. H. ve Hwang, J. (2011). Luxury marketing: The influences of psychological and demographic characteristics on attitudes toward luxury restaurants. International Journal of Hospitality Management, 30, 658669.

Lee, W. J., Phau, I. ve Roy, R. (2012). Status and nanstatus consumers'attitudes toward foreign and domestic luxury brands of underwear. Journal of International Consumer Marketing, 24, 43-56. 
McKinsey (1990). The luxury industry. Paris: McKinsey Corp.

Megehee, C. M. ve Spake, D. F. (2012). Consumer Enactments of archetypes using luxury brands. Journal of Business Research, 65, 1434-1442.

Miller, K. W. ve Mills, M. K. (2012). Contributing clarity by examing brand luxury in the fashion market. Journal of Business Research, 65, 14711479.

Moore, C. M. ve Birtwistle, G. (2004). The Burberry business model: Creating an international luxury fashion brand. International Journal of Retail and Distribustion Management, 32, 412-422.

Netemeyer, R. G. Krishnan B., Pullig, C., Wang, G., Yagci, M., Dean, D., Ricks, J., ve Wirth F. (2004). Developing and validating measures of facets of customer-based brand equity. Journal of Business Research, 57, 209-224.

Nia, A. ve Zaichkowsky, J. L., (2000). Do counterfeits devalue the ownership of luxury brands?. Journal of Product and Brand Management, 9, 485-497.

Nueno, J. L. ve Quelch, J. A. (1998). The mass marketing of luxury. Business Horizons, November-December, 61-68.

Onkokwo, U. (2007). Luxury fashion branding: Trends, tactics and techniques. ed. London: Palgrave Macmillan.

Oxford, D., (2017). Oxford living dictionaries. [Online] Available at: https://en.oxforddictionaries.com/definition/luxury Accessed 20 November 2017.

Parguel, B., Delecolle, T. ve Florence, P. V. (2016). How price display influences consumer luxury perceptions. Journal of Business Research, 69, 341-348.

Phau, I. ve Prendergast, G. (2000). Consuming luxury brands: The relevance of the "rarity principle". Journal of Brand Management, 8, 122-138.

Phau, I., Teah, M. ve Chuah, J., (2015). Consumer attitudes towards luxury fashion apparel made in sweatshops. Journal of Fashion Marketing and Management, 19, 169-187.

Prendergast, G. ve Wong, C. (2003). Parental influence on the purchase of luxury brands of infant apparel: An exploratory study in Hong Kong. Journal of Consumer Marketing, 20, 157-169.

Riley, F. D., Pina, J. M. ve Bravo, R. (2015). The role of perceived value in vertical brand extension of luxury and premium brands. Journal of Marketing Management, 31, 881-913. 
Roper, S., Caruana, R., Medway, D. ve Murphy, P. (2013). Constructing luxury brands: Exploring the role of consumer discourse. European Journal of Marketing, 47, 375-400.

Salezadeh, R. ve Pool, J. K. (2017). Brand attitude and perceived value and purchase intention toward global luxury brands. Journal of International Consumer Marketing, 29, 74-82.

Shukla, P., Banerjee, M. ve Singh, J. (2016). Customer commitment to luxury brands: Antecedents and consequences. Journal of Business Research, 69, 323-331.

Silverstein, M. L., Fiske, N, ve Butman, J. (2005). Trading up: the New American luxury. , New York: Boston Consulting Group.

Siu, N. Y.-M., Kwan, H. Y. ve Zeng, C. Y. (2016). The role of brand equity and face saving in chinese luxury consumption. Journal of Consumer Marketing, 33, 245-256.

Smith, A. (1776). An inquiry into the nature and causes of wealth of nations. London: W. StrahanveT. Cadell.

Sreejesh, S., Sarkar, A. ve Roy, S. (2016). Validating a scale to measure consumer's luxury brand aspiration. Journal of Product and Brand Management, 25, 465-478.

Sweeney, J. C. ve Soutar, G. N. (2001). Consumer perceived value: The development of a multiple item scale. Journal of Retailing, 77, 203-220.

Thomas, D. (2008). Deluxe: How Luxury Lost its Luster. New York: Thorndike Press.

Truong, Y., McColl, R. ve Kitchen, P. J. (2009). New luxury brand positioning and the emerge of masstige brands. Journal of Brand Management, 16, 375-382.

Truong, Y., McColl, R. ve Kitchen, P. J. (2010). Uncovering the relationships between aspirations and luxury brand preference. Journal of Product and Brand Management, 19, 346-355.

Tynan, C., McKechnie, S. ve Chhuon, C. (2010). Co-creation value for luxury brands. Journal of Business Research, 63, 1156-1163.

Uggla, H. (2016). Leveraging luxury brands: Prevailing trends and research challenges. Journal of Brand Management, 13, 34-41.

Veg-Sala, N.ve Roux, E. (2014). A semiotic analysis of the extendibility of luxury brands. Journal of Product and Brand Management, 23, 103-113 
Vickers, J. S. ve Renand, F. (2003). The marketing of luxury goods: An expletory study-the conceptual dimensions. The Marketing Review, 1 December, 3, 459-478.

Vigneron, F. ve Johnson, L. W. (1999) A review and a conceptual framework of prestige-seeking consumer behavior. Academy of Marketing Review.

Vigneron, F. ve Johnson, L. W. (2004). Measuring perceptions of brand luxury. Journal of Brand Management, 11, 484-506.

Wang, S.-C., Soesilo, P. K. ve Zhang, D. (2015). Impact of luxury brand retailer co-branding strategy on potential customers: A cross-cultural study. Journal of International Consumer Marketing, 27, 237-252.

Wetlaufer, S., (2004). Perfect paradox of star brands: An interview with bernard arnoult of LVMH. Harvard Business REview, - -, pp. - .

Wiedmann, K.-P., Hennings, N. ve Siebels, A. (2009). Value Based segmentation of luxury consumption behavior. Psychology and Marketing, 26, 625-651.

Yang, W. ve Mattila, A. S. (2014). Do affuluent customers care when luxury brands go mass? The role of product type and status seeking on luxury brand attitude. International Journal of Contemporary Hospitality Management, 26, 526-543.

Yoo, J. ve Park, M. (2016). The Effect of e-mass customization on consumer perceived value, satisfaction, and loyalty towards luxury brands. Journal of Business Research, 69, 5775-5784.

\section{Kaynakça Bilgisi / Citation Information}

Habiboğlu, Ö. ve Uslu, A. (2019). Algılanan lüks marka değerinin ve marka itibarının premium fiyat ödeme istekliliği üzerindeki etkisi. OPUS-Uluslararası Toplum Araştırmaları Dergisi, 14(20), 1680-1709. DOI: 10.26466/opus.572789 